ship. If a university is not a great force, if the members of a university are not a great force in that decision, then who is ? Where are we to look for it ? In this crisis in civilisation there is a terrific responsibility on university graduates for elasticity of mind, probity and clarity of judgment, and industry of thought on the concrete issue before them. There are many great issues on moral principles in these days, when the widely-held view is that the proper place for a path is the edge of the precipice. The world is full of good people who are thoroughly muddle-headed; this is a time for level-headed decisions and carefully worked out ones. Sir Josiah concluded with a call to the students to be true to the great ideals the university has given them; and to try to make the university what he believes it ought always to be--somewhere where the reasoned thought and soul of our country can have the perpetual association of great ideas, the discipline of serious and persistent aims, the purification of candid and purging humour, and lastly the company of souls that are kindled to noble purposes.

\section{Society for Psychical Research}

THE last of the jubilee meetings of the Society for Psychical Research was held on July 4 at the Conway Hall, when Dr. William Brown, Wilde reader in mental philosophy in the University of Oxford, lectured on "Psychology and Psychical Research". The president, Sir Oliver Lodge, took the chair. Dr. Brown said that hypnotic and psycho-analytic investigations have greatly supplemented the theory of the 'subliminal self' first propounded by F. W. H. Myers, one of the founders of the Society for Psychical Research, without, however, really supplanting it. The employment of the statistical method on large numbers of cases is entirely in the spirit of strict science, yet the predominantly negative results recently obtained along these lines as regards manifestations of telepathy and clairvoyance should not blind the public to the possibility of such phenomena in special cases and under special conditions. The intensive study of well-attested individual cases is needed to correct the balance, and it is especially along this line that the Society for Psychical Research has done much useful work. One might base one's belief in survival most firmly on general philosophical and religious considerations as to the nature and value of human experience; nevertheless, the sum total of evidence of a scientific nature accumulated by the Society for Psychical Research in support of survival is far from negligible.

\section{Marconi Beam Stations for Shanghai}

New Marconi transmitting and receiving stations are to be erected near Shanghai for the operation of the proposed short-wave beam services between China and Europe and the United States. A unique feature of the installation will be the inclusion of auxiliary Marconi apparatus enabling the transmitters to be utilised for broadcasting services when they are not in use for telegraphic communications. The auxiliary apparatus for this purpose consists of a modulating equipment which can be connected to either of the telegraph transmitters to provide telephone signals of broadcasting quality. A complete set of Marconi studio equipment is also to be supplied to enable the service to be conducted in accordance with the most modern practice. The aerial system of the transmitting station is of particular interest. For the commercial telegraph services to Europe, of which the principal is the service to Great Britain, two bays of beam aerials, accurately oriented to concentrate their signals on the receiving stations, are to be erected, one being tuned to the wave-length of 17 metres and the other to 26 metres, the wave-lengths allotted to these circuits. A third beam aerial array will be directed on San Francisco for the American service. In addition, there will be four omni-directional aerials, one of which will be used for broadcasting. The others are provided to afford the station the maximum flexibility in the range and extent of its telegraphic services. At the receiving station four high-speed commercial service receivers of the Marconi beam type are to be installed, with two beam aerial systems directed on Europe and two on San Francisco. Four omni-directional receiving aerials are also to be supplied for the reception of short-wave signals from other countries with which beam services are not required. On the completion of these stations near Shanghai a direct commercial wireless circuit will be provided for the first time between Great Britain and China.

\section{Emergency Lighting Sets}

IN addition to the usual source of electric power for supplying lamps and signalling devices, it is somet imes necessary, in order to safeguard life and property, to have another source of power that can be available in emergency. Such additional sources are necessary for theatres, cinemas, hospitals, and for all large buildings through which there is a continuous stream of traffic. Up to the present time, storage batteries have often been used for this purpose, but their drawbacks are their expense and the gases they develop, often necessitating the use of a large separate room. A petrol electric set has sometimes been suggested, but there is frequently difficulty in starting it after a long period of standstill. Fire risks also impose restrictions in the selection of rooms for these sets. In a recent issue of Allgemeine Elektricitäts Gesellschaft (A.E.G.) Progress, a new emergency lighting set is described which eliminates practically all these difficulties. It consists simply of a small water turbine, which can be connected to the municipal water mains and drives a direct current generator (turbinamo). The water supply to the turbine is normally cut off. Should the normal supply voltage fall for any reason, an electro-magnet ceases to act and so a cut-off device is released, and the pressure of the water in the mains opens a valve and the machine rotates. The water pressure required is anything between 3 and 6 atmos. $(42 \cdot 5-85 \mathrm{lb}$. per sq. in.). The lighting set has a vertical axis, and takes up very little space. It should be placed near the water supply mains. As a disturbance rarely occurs, and lasts only very little time, the cost of the water used is negligible.

No. 3271, VoL. 130] 